\title{
2010-2014: A COMPARATIVE EVOLUTION OF SUSTAINABILITY REPORTING AND ITS ASSURANCE IN EUROPE AND THE U.S.A.
}

\author{
Diana-Maria TÎNJALĂ 1 \\ Lavinia Mirela PANTEA 2 \\ Alexandru BUGLEA 3
}

DOI: 10.1515/tjeb-2015-0004

\begin{abstract}
The concept of sustainability has evolved to encompass environmental, social and governance issues regarding corporate behaviour. For the last few years, stakeholders have begun putting pressure on companies to report on sustainability issues. Several national and international regulations and standards have been adopted to guide companies in their reporting. To ensure the accuracy and comparability of non-financial data needed for the stakeholders' decision making process, there is an increasing preference for the external assurance of sustainability reporting. The internationally recognized CSR report assurance standards are the International Standard on Assurance Engagements, ISAE 3000, and AccountAbility's AA1000 Assurance Standard (AA1000AS). This study focuses on the evolution of corporate sustainability reporting, using two non-financial indicators: ESG reporting, and Assurance of ESG reporting. The data for the study is based on content analysis of both CSR reports and corporate websites, courtesy of Sustainalytics. We assessed the evolution of the two indicators from June 2010 to February 2014, for 50 listed European companies and 50 American ones. The comparative approach illustrates the different evolutions of sustainability in Europe and the USA, emphasising the need for stronger regulations and guidelines in the USA, similar to those already implemented in European Countries. For the selected time period, US companies are shown to be worse reporters than European ones, having a negligible number of reports externally verified.
\end{abstract}

Keywords: $\quad$ Sustainability reporting, ESG, Assurance standards, ISAE 3000, AA1000AS.

JEL Classification:Q01, Q56.

Abbreviations: AA1000AS: AccountAbility's AA1000 Assurance Standard;

CSR: Corporate Social Responsibility;

ESG: environmental, social, governance;

GRI: Global Reporting Initiative;

IR: Integrated Reporting;

ISAE 3000: International Standard on Assurance Engagements;

Rl: responsible investors;

SR: Sustainable reporting.

\footnotetext{
1, 2 PhD Student, West University of Timisoara, Romania

${ }^{3}$ Professor PhD, West University of Timisoara, Romania
} 
Tînjală, D.-M., Pantea, L. M., Buglea, Al. (2015).

2010-2014: A Comparative Evolution of Sustainability Reporting and its Assurance in Europe and the U.S.A.

\section{Introduction}

This study seeks to analyze the evolution of corporate sustainability reporting practice in European listed companies, as opposed to US companies, with the help of two non-financial indicators: ESG (environment, social and governance) reporting, and Assurance of ESG reporting. As explained in the research methodology part of the paper, the first indicator assesses whether the companies analyzed publish a non-financial information report, usually referred to as a sustainability report or a CSR report, while the second indicator pertains to the verification of the report by an independent third-party assurance provider.

In order to better understand the purpose and results of the study, it is important to know several information about the sustainability background in which listed companies operate, which constitute the literature review section. What is nowadays perceived as sustainability is the company's non-financial influence on stakeholders: investors, employees, governmental authorities, communities, the media and so on. The concept of sustainability has evolved due to the global problems that humanity is facing such as: pollution, globalisation, poverty, high unemployment rates, human rights violations and corruption. Considering the impact large corporations have on global economy, which seldom surpasses that of governments, stakeholders ask of them to implement sustainability policies.

Nowadays seen as the norm, corporate reporting on sustainability policies and actions has evolved so much in the last two decades that specialists are already talking about a new form of reporting. Integrated reporting is meant to show the true added value of the company, both economical and social. Nevertheless, sustainability reporting still faces several problems, such as a lack of homogeneity and comparability of data, due to nonexistent mandatory regulations on the matter. Several international guidelines, such as the Global Reporting Initiative G4 and the United Nations Global Compact are in place, together with dozens national standards and regulations.

However, due to the increasing number of guidelines that allow companies to choose whichever they favour, the terminology of sustainability has become vague and suffers changes from one company to the other. In this situation, in order to ensure at least a limited reliability of data reported, assurance of CSR reports is recommended for companies that want to prove they go beyond a simple regulatory compliance. The assurance providers can be accountancy firms, engineering firms or sustainability analysis firms, depending on the reporting company's purpose.

We have analyzed 100 companies from two major geographic regions - Europe and the USA and compared their trend for CSR reporting. Our methodology included the content analysis method and stratified sampling. The findings and discussion section of the paper follows

\section{DE GRUYTER OPEN}

Timisoara Journal of Economics and Business | ISSN: 2286-0991 | www.tjeb.ro Year 2015 | Volume 8 | Issue 1s | Pages: 48-69 
Tînjală, D.-M., Pantea, L. M., Buglea, Al. (2015).

2010-2014: A Comparative Evolution of Sustainability Reporting and its Assurance in Europe and the U.S.A.

closely on the importance of non-financial data, calculating for every one of the 100 companies included in the study the score for ESG reporting (between one of the five categories: 0 score, 25 score, 50 score, 75 score or 100 score) and for Assurance of ESG reporting (same score categories). The score category depends on the type of sustainability report published and on the depth of assurance, respectively. The study offers in the conclusion section several ideas for further research.

Compared to previous works on this topic, this study uses newer data and focuses on the comparison between European and American companies, in light of the new European regulations issued after June 2010 , compared to the lack of sustainability criteria in the listing and operating of American companies.

\section{Literature Review}

\subsection{Sustainability Reporting}

The inequality between finite resources and infinite needs has concerned mankind for centuries. However, its social and environmental implications have begun being debated in economic literature in the mid-1980, being influenced by the World Commission on Environment and Development (WCED)'s 1987 report "Our common future” (Pezzey \& Toman, 2002). The report records the most influential definition of sustainable development: „Humanity has the ability to make development sustainable to ensure that it meets the needs of the present without compromising the ability of future generations to meet their own needs" (WCED, 1987, p.16).

Ever since, the terminology concerned with sustainability has evolved, including terms such as: sustainability, ethical footprint, ecological rucksacks, the triple bottom line, corporate social responsibility (CSR), corporate social performance (CSP), organisational social responsibility, moral muteness, responsible entrepreneurship and many others (Baden \& Harwood, 2013; Milne \& Gray, 2013).

However, despite of the rich literature on the subject, sustainability remains a vague concept (Milne \& Gray, 2013), having been argued that it has and will meet with unavoidable conflicts because of its competing goals - sustainable environment, sustainable consumption rates, sustainable employment rates (Norgaard, 1988). Because of its ambiguity, the term has usually been presented together with CSR, the latter being defined as "the commitment of business to contribute to sustainable economic development, working with employees, their families, the local community and society at large to improve their quality of life"(WBCSD 2002a, p. 6).

\section{DE GRUYTER OPEN}

Timisoara Journal of Economics and Business | ISSN: 2286-0991 | www.tjeb.ro Year 2015 | Volume 8 | Issue 1s | Pages: 48-69 
Tînjală, D.-M., Pantea, L. M., Buglea, Al. (2015).

2010-2014: A Comparative Evolution of Sustainability Reporting and its Assurance in Europe and the U.S.A.

For our purposes, corporate sustainability concerns three non-economic dimensions: environmental, social and governance (ESG), that the enterprise can influence through its actions or lack of action. Each of these dimensions is composed of several items, such as the ones described by the European Commission in its 2011 strategy on corporate social responsibility: social, ethical, human rights, consumer rights and environmental concerns. In order for a company to be called socially responsible, it needs to tend not just to the needs of its shareholders, but also to all of the above-mentioned concerns of its stakeholders (European Commission, 2011).

Businesses engagement with sustainability-related concepts has taken the form of voluntary reporting on this non-financial information. Early reporting (previous to mid 1990s) was mostly in a narrative form as part of the company's annual report. The reporting provided little value as the information was not comparable throughout the region or the industry (Tschopp \& Nastanski, 2013). Moreover, in these reports, the terms "sustainability” or "sustainable development" were almost never used, and when used, they were not defined (Milne \& Gray, 2013).

Sustainability reporting has evolved throughout the last two decades (A. Christofi, P. Christofi \& Sisaye, 2012), so have its requirements, converging towards a harmonization of reporting standards and concept definitions:

- „We define sustainable development reports as public reports by companies to provide internal and external stakeholders with a picture of corporate position and activities on economic, environmental and social dimensions" (WBCSD 2002b, p 7);

- „Sustainability reporting at the enterprise level... aims to represent an enterprise's environmental, social and economic performance and the relate impacts on the world around it" (ICAEW 2004, p. 12);

- "The information should not be restricted to the financial aspects of the undertaking's business, and there should be an analysis of environmental and social aspects of the business necessary for an understanding of the undertaking's development, performance or position" (EU, 2013, art.26);

- "we have defined sustainability reports as reports that include quantitative and qualitative information on their financial/economic, social/ethical and environmental performance in a balanced way" (KPMG, 2002, p.7).

Due to the theoretical challenges of sustainability, the empirical literature on the subject was slow to evolve, the first impactful paper being considered Pearce and Atkinson's 1993 "Capital Theory and the Measurement of Sustainable Development: An Indicator of 'Weak' Sustainability" that measures the overall sustainability of economies (Pezzey \& Toman, 2002).

\section{DE GRUYTER OPEN}

Timisoara Journal of Economics and Business | ISSN: 2286-0991 | www.tjeb.ro Year 2015 | Volume 8 | Issue 1s | Pages: 48-69 
Tînjală, D.-M., Pantea, L. M., Buglea, Al. (2015).

2010-2014: A Comparative Evolution of Sustainability Reporting and its Assurance in Europe and the U.S.A.

Nowadays, given the exponential increase in CSR reports - from 44 reports following GRI guidelines in 2000 to 1973 in 2010 (Ioannou \& Serafeim, 2011), the present stage of empirical works on sustainability focuses on the analysis of CSR reports and their relation to primary stakeholders (Deloitte, 2012; KPMG, 2013; European Comission, 2013; CSES, 2011; Bassen \& Kovacs, 2008; Anis, Lala-Popa, Cican, \& Tarta (Blaga), 2012). All the information disclosed is no longer meant to be just a marketing tool, but criteria for stakeholders to base their decisions on (Tschopp \& Nastanski, 2013).

Additionally, taking into account that strict regulatory requirements are not yet enforced, many national, regional and international initiatives started issuing voluntary sustainability reporting guidelines. The Global Reporting Initiative (GRI) is a relatively new initiative; it was founded in Boston, in 1997 as a department of the Coalition for Environmentally Responsible Economies (CERES) and became an independent institution in 2001. The first version of the Guidelines was launched in 2000. A second generation of its guidelines, known as G2, was brought out in 2002 at the World Summit on Sustainable Development in Johannesburg and the third generation of guidelines, G3, was issued in 2006. The most recent generation of guidelines are GRI G4, launched in May 2013. These most recent guidelines have increased user-friendliness and accessibility and are more focused on materiality, offering the opportunity for companies to produce more focused reports (GRI, 2014).

GRI provides a set of performance indicators with guidelines for measurement (Moore, 2012) and third party assurance. The companies aiming to follow these guidelines are free to choose which indicators to measure and even according to which level they wish to report. The guidelines are not purely focusing on their companies' disclosure of economic, environmental, social and governance performance, but they are also aiming to help them identify business risks and opportunities due to these parameters. GRl's reporting framework consists of reporting guidelines, sector supplements, national annexes and various protocols.

The GRI's mission is to make sustainability reporting a standard practice by providing guidance and support to corporations (Sen \& Das, 2013). According to a recent study-survey (KPMG, 2013), GRI is the most widely used voluntary reporting framework, exceeding by far the use of national standards and other guidelines. The survey shows that among the 100 largest companies in 41 countries, over $78 \%$ refer to the GRI in their sustainability reports, which reflects an increase of $9 \%$ since 2011. If we consider the world's largest 250 companies, the survey shows that the GRI reporting rate increased from 78\% in 2011 to $82 \%$ in 2013 . The companies that do not refer to the GRI framework state that they use their own in-house developed frameworks, national reporting guidelines or no guidelines at all.

Another important international framework on sustainability reporting is the United Nations Global Compact (UNGC) that comprises ten principles on anti-corruption, human rights,

\section{DE GRUYTER OPEN}

Timisoara Journal of Economics and Business | ISSN: 2286-0991 | www.tjeb.ro Year 2015 | Volume 8 | Issue 1s | Pages: 48-69 
Tînjală, D.-M., Pantea, L. M., Buglea, Al. (2015).

2010-2014: A Comparative Evolution of Sustainability Reporting and its Assurance in Europe and the U.S.A.

labour and the environment. Business participants in the UNGC commit to upholding the ten standards throughout their activities, and issue an annual Communication on Progress (COP) report, to illustrate the evolution in implementing the principles (UNGC, 2014).

According to the Centre for Strategy and Evaluation Services' report (CSES, 2011), the GRI and the UNGC are the most used sustainability reporting frameworks. Furthermore, empirical evidence indicates that GRI guidelines are especially used by large companies that disclose information in the form of a more comprehensive report, while UNGC Communication on Progress (UNGC COP) is used by both large companies and SMEs.

The AA1000 AccountAbility Principles Standard is another widely recognized international standard for reporting on social and environmental issues (Tschopp \& Nastanski, 2013). The standard aims to create accountable organisations that involve stakeholders in identifying and solving sustainability issues.

Aside from the three well-known international standards, several national institutions have developed their own mandatory frameworks for sustainability reporting, including: in South Africa, the King code of Governance Principles for South Africa also referred to as the King III was released in 2009 (van Zyl, 2013); in France, the Grenelle II Act was passed in 2012; Denmark, Norway and the Netherlands have put in place environmental reporting requirements since 1996 (Daizy, Mitali, \& Niladri, 2013). Other countries, such as India or Germany, have chosen to provide companies with guidelines for voluntary reporting: in India, in July 2011, the Ministry of Corporate Affairs released the Voluntary Guidelines on Social, Environmental and Economic Responsibilities of Business (GIZ et al., 2012); in Germany, the German Society of Investment Professionals (DVFA, 2010) developed a guideline for corporations on how to report on ESG, completed with general and sectorspecific key performance indicators (KPIs).

The number of national and regional organisations issuing ESG guidelines or requirements has drastically increased over the last few years, with the creation and development of integrated reporting. According to the International Integrated Reporting Council (IIRC), the communication between a company and its external environment should consist of both quantitative and qualitative information, in order to better explain how a company creates value over time (IIRC, 2013). Integrated reporting (IR) demonstrates the two-way connection between a company's strategy and global performance and the external environment in which it operates. IR is seen as a solution to the major weaknesses of sustainability reporting: failing to provide a link with the organisation's strategy (van Zyl, 2013), covering few stakeholders and addressing only a few ESG issues selected by the company (Milne \& Gray, 2013).

\section{DE GRUYTER} OPEN Year 2015 | Volume 8 | Issue 1s | Pages: 48-69 
Tînjală, D.-M., Pantea, L. M., Buglea, Al. (2015).

2010-2014: A Comparative Evolution of Sustainability Reporting and its Assurance in Europe and the U.S.A.

In the last few years, there has been a noticeable harmonization movement concerning sustainability reporting guidelines and other CSR-related initiatives, such as the ISO standards: ISO 14000 family on environmental management, ISO 9001 on quality management system and the recent ISO 26000 regarding guidance on social responsibility.

\subsection{Assurance of Sustainability Reporting}

In the past decade, it has also became standard practice to have sustainability reports externally assured. According to KPMG's 2013 Survey of Corporate Responsibility Reporting, more than half of the world's 250 largest companies, based on the Fortune Global 500 ranking for 2012, are now investing in assurance; the other corporations are expected to follow this trend in the near future.

The International Federation of Accountants (IFAC) defines an assurance engagement as one "in which a practitioner expresses a conclusion designed to enhance the degree of confidence of the intended users ... about the outcome of the evaluation or measurement of a subject matter against criteria." (IAASB, 2012, p.16.)

The external assurance of sustainability reporting is favoured by multiple stakeholders as they need relevant and accurate information for decision making. Moreover, many companies need external assurance for their sustainability reports in order to meet the requirements of sustainability indices. External assurance has several advantages: it increases the stakeholder's trust in the company, guaranteeing that the sustainability report of the company is based on facts; it also aims to eliminate or at least reduce companies' exaggerations on their social and environmental credentials; and it often allows for a better comparability between reports written in different sectors or countries. However, there are also many limitations, such as the difficulty of measuring and assessing the company's impact on environmental, social and governance issues based on both the quantitative and qualitative data included in a CSR report. Nevertheless, sustainability reporting is meant to be reliable and credible, making independent assurance by external assurance providers a necessity (O'Dwyer \& Owen, 2007).

The external assurance of sustainability reporting differs greatly from the external audit of financial reporting. While for financial data there are mandatory international procedures for reporting and audit, external assurance of sustainability reports is still voluntary in most countries, with just France and South Africa pioneering a mandatory approach among the 41 countries surveyed by KPMG (KPMG, 2013). International assurance standards for sustainability disclosure have started to be developed in the last years, but they still vary in approach and are not widely used.

\section{DE GRUYTER OPEN}

Timisoara Journal of Economics and Business | ISSN: 2286-0991 | www.tjeb.ro Year 2015 | Volume 8 | Issue 1s | Pages: 48-69 
Tînjală, D.-M., Pantea, L. M., Buglea, Al. (2015).

2010-2014: A Comparative Evolution of Sustainability Reporting and its Assurance in Europe and the U.S.A.

According to the Global Reporting Initiative, there are three types of external assurance providers for sustainability disclosures:

- Accountancy firms, which have expertise in financial and non-financial reporting and have their own systems, controls and audit/assurance procedures;

- Engineering firms, which normally offer technical certifications and engineering expertise and are mainly used for risk-based analysis, applying a multi-disciplinary approach; and

- Sustainability services firms, whose focus and expertise is on sustainability related issues. They are smaller than the others assurance providers and are usually locally based.

External assurance providers are expected to publish an independent, objective and impartial opinion and conclusion of their assessment. The external assurance statement also needs to mention the level of assurance. This indicates the extent and depth of the work the assurance provider will undertake, and therefore the degree of confidence for each report. There are two levels of assurance: "reasonable assurance" (high but not absolute) or "limited assurance" (moderate). The higher the level of assurance, the more rigorous the assurance process is. If an auditor reports that a company's CSR report is "reasonably assured", this means a level of confidence certifying that the company's statements are not materially misstated. Whereas "limited assurance" refers to a lower level of confidence with a higher risk of the company's statements being materially misstated. Additionally, a sustainability report can be fullly or only partially assured, or an organization may choose to have a reasonable level of assurance for some indicators and limited for others.

Although several countries have published sustainability assurance standards, there are only two internationally recognized assurance standards: the ISAE 3000 and the AA1000AS (Manetti \& Becatti, 2008).

\section{ISAE 3000}

The International Standard on Assurance Engagements, ISAE 3000 covers assurance engagements other than audits or reviews of historical financial information. The standard was developed by The International Auditing and Assurance Standards Board (IAASB) of the International Federation of Accountants (IFAC) and was firstly published in 2003. Several updates took place since then; the last version was published in December 2013 and will become effective for assurance engagements where the assurance report is dated on or after 15 December 2015 (IAASB, 2013).

According to Manetti and Becatti (2009), the most important elements of the ISAE 3000 are: determining the level of assurance (reasonable assurance or limited assurance); the possibility to use interdisciplinary teams of experts; the types of verifications and tests to implement; the evaluation of audit risk; suitable reporting criteria; and the form of the final assurance statement.

\section{DE GRUYTER OPEN}

Timisoara Journal of Economics and Business | ISSN: 2286-0991 | www.tjeb.ro Year 2015 | Volume 8 | Issue 1s | Pages: 48-69 
Tînjală, D.-M., Pantea, L. M., Buglea, Al. (2015).

2010-2014: A Comparative Evolution of Sustainability Reporting and its Assurance in Europe and the U.S.A.

However, the same authors identify several important weaknesses of the ISAE 3000, the most important being that it was not specifically designed for assurance services on sustainability reports. Another weakness is the lack of connection to financial auditing, which may encourage fraud and can result in the inability to verify compliance with national law and regulations. Moreover, ISAE 3000 does not offer the stakeholders' representatives the chance to be involved in the verification process of the materiality and relevance of the information disclosed. (Manetti and Becatti, 2009)

\section{AA1000AS}

AccountAbility is an advisory services firm focused on mainstreaming sustainability into organizational thinking and practice. To support this, it has developed the AA1000 Series of Standards, which addresses "issues affecting governance, business models and organizational strategy ... The AA1000 standards are designed for the integrated thinking required by the low carbon and green economy, and support integrated reporting and assurance".

The AA1000 Series of Standards include the AA1000 AccountAbility Principles Standard (AA1000APS) - a framework for organisations to identify, prioritize and respond to its sustainability challenges, the AA1000 Assurance Standard (AA1000AS) which provides the methodology to evaluate the nature and extent to which an organization adheres to the AccountAbility Principles, and the AA1000 Stakeholder Engagement Standard (AA1000SES) designed to help organizations ensure stakeholder engagement processes are purpose driven, robust and deliver results (AccountAbility, 2008).

Some advantages for using this assurance standard include its approach based on stakeholders "needs, its flexibility for different size organisations and its materiality determination process (AccountAbility, 2008, 2014). The standard is developed through a multi-stakeholder consultation process and is used by a broad spectrum of organizations, from multinational businesses to small and medium enterprises, governments and civil societies (GRI, 2013).

\section{Research Methodology}

The main objective of this paper is to contribute to the current status of the literature by providing data analysis regarding corporate sustainability. Moreover, we also try to portray a comparative evolution on sustainability reporting in two major regions. The research hypothesis is that sustainability reporting done by companies listed on international stock exchanges has improved during the past 5 years.

\section{DE GRUYTER OPEN}

Timisoara Journal of Economics and Business | ISSN: 2286-0991 | www.tjeb.ro Year 2015 | Volume 8 | Issue 1s | Pages: 48-69 
Tînjală, D.-M., Pantea, L. M., Buglea, Al. (2015).

2010-2014: A Comparative Evolution of Sustainability Reporting and its Assurance in Europe and the U.S.A.

We used content analysis to portray the evolution of corporate sustainability reporting for 100 companies - half from Europe and half from the United States of America, throughout the time frame 2010 -2014. Content analysis was developed as a social science research technique that allows the analysing of qualitative data from documents used in communication. The method's purpose is to make valid inferences from the data to its context. (Krippendorff, 1989)

\subsection{Data}

This study uses data from the Sustainalytics database. Sustainalytics is an ESG research and analysis firm that provides data for responsible investors worldwide. The company has been a part of the sustainability analysis market for more than 20 years and, at present, it provides global research coverage through its 14 offices. Its clients include financial institutions, asset managers, pension funds, international organisations, private companies and the academic environment.

The population data comprises 4676 companies listed on stock exchanges worldwide, that Sustainalytics has analyzed annually starting in January 2010 or later. The data collection method did not change over the years; however, due to the increasing concern towards corporate sustainability, several hundred companies have been added to the database every year.

For the selection of the sample of companies, we took into account the following considerations:

- The companies should be headquartered in Europe or the USA. We chose these two geographic regions due to their regulatory differences concerning sustainability - Europe being the most regulated, and USA lagging behind on regulations.

- The companies should have been included in the database previously to June 2010 and to have been continuously analyzed for all 5 years.

We were left with 255 European companies, from which only one was from a non-EU country, and 259 American ones. We proceeded to stratified sampling, by using the RAND function in Microsoft Office Excel and sorting the records ascending by its value, selecting only the first 50 companies from each category - European (we were left with companies headquartered exclusively in the European Union), and American companies. Because we did not focus on a specific sector, but a general trend, we consider that analyzing 100 companies is sufficient to establish the direction in which sustainable reporting is moving. The name, country and peer group for the 100 companies used in this study can be found in Appendix A.

As seen in Appendix A, the companies represent many sectors and countries. France and the United Kingdom are best represented for the European companies' category, each by 9 companies, followed by Sweden and Germany, each with 7 companies. With regards to the sector of activity, the banking sector and the media is best represented. For American

\section{DE GRUYTER OPEN}

Timisoara Journal of Economics and Business | ISSN: 2286-0991 | www.tjeb.ro Year 2015 | Volume 8 | Issue 1s | Pages: 48-69 
Tînjală, D.-M., Pantea, L. M., Buglea, Al. (2015).

2010-2014: A Comparative Evolution of Sustainability Reporting and its Assurance in Europe and the U.S.A.

companies, the leading sectors as number of cases analyzed are Machinery (6 cases) and Utilities ( 5 cases).

Further methodological developments could consider a sector analysis, taking into account that, at least for the environmental pillar of ESG, sectors susceptible to having a high impact on the environment tend to report more on sustainability than services sectors (Baden \& Harwood, 2013).

\subsection{Data Analysis}

The purpose of this analysis is to provide a dynamic comparison of the evolution of sustainability reporting in Europe and North America from 2010 to February of 2014. To this end, we used annual Sustainalytics data based on content analysis of CSR reports and corporate websites. We focused on two corporate governance indicators: ESG reporting, and Assurance of ESG reporting.

The first indicator pertains to how a company reports on ESG issues and whether it complies with international or national guidelines and best practices. This indicator looks into the quality of the ESG reporting and whether it is integrated fully into all corporate disclosures or just in the Annual Reports or other risk management policies. A strong CSR disclosure should be integrated with financial reporting, follow international standards (such as the GRI), be externally verified and cover not just the policies and documents, but also the implementation of sustainability related matters and the social performance of the company.

The current corporate practice in both Europe and the U.S.A. is to release two separate reports: one for financial performance and the other for sustainability performance. Sustainability reports issued separately should still be assessed based on the quality of reporting. The company must be able to demonstrate that its reports are used as a management tool and that sustainability is integrated in its business operations. Reports that focus on philanthropic and sponsorship activities or provide a general overview of ESG issues are not considered sustainability reports and should be given the lowest answer category as these reports consider CSR reporting as a public relations strategy rather than a management tool.

In order to ensure the comparability and uniformity of the data analyzed, we have coded the communication from the company was using a score-based method found in Table 1. However, the GRI G4 guidelines launched in May 2013 replace the A, B, C Application Levels with two "In Accordance" levels - "Core and Comprehensive". However, because the transition period to G4 standards was not finalised in the studied time frame, we have used the categories listed in Table 1 to assess the quality of CSR reporting.

The second indicator verifies whether the CSR report is externally verified according to recognized standards. The international recognized standards are ISAE 3000 and AA1000. However, depending on the country the company operates in, national standards can also be used to assess the quality of non-financial disclosure. A list of the recognised national

\section{DE GRUYTER OPEN} Year 2015 | Volume 8 | Issue 1s | Pages: 48-69 
Tînjală, D.-M., Pantea, L. M., Buglea, Al. (2015).

2010-2014: A Comparative Evolution of Sustainability Reporting and its Assurance in Europe and the U.S.A.

standards can be found under the Literature Review section of this paper. Similarly, in order to use qualitative data in our analysis, we used a scoring method as seen in Table 2.

Table 1. Scoring categories for the ESG reporting indicator

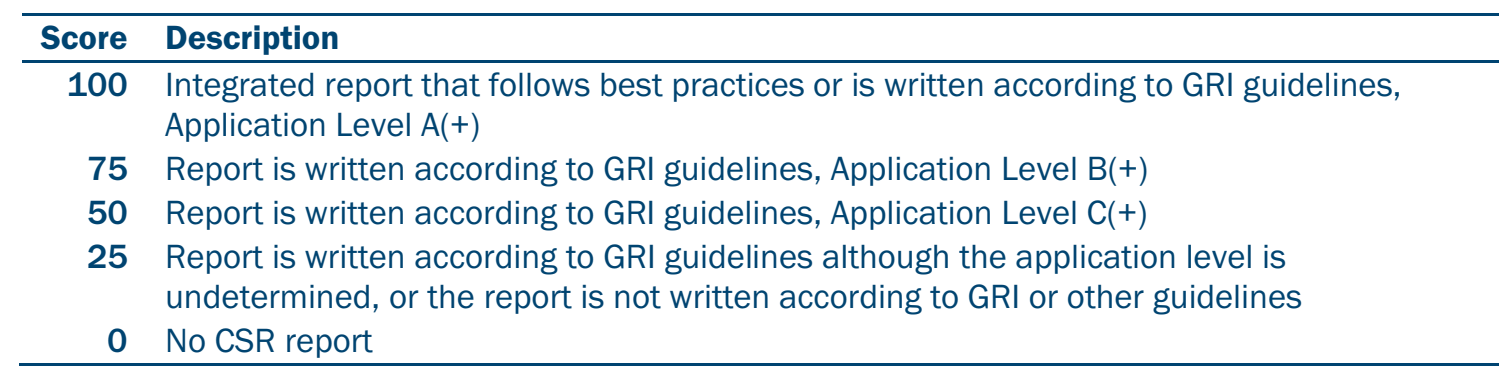

Source: Adapted from Sustainalytics' framework

Table 2. Scoring categories for the Assurance of ESG reporting indicator

\begin{aligned} \hline Score & Description \\ \hline 100 & $\begin{array}{l}\text { The entire CSR report was externally verified according to international or national } \\ \text { recognized standards and received "reasonable" or "high assurance". }\end{array} \\ \mathbf{7 5} & \begin{array}{l}\text { The entire CSR report was externally verified according to other report auditing standards } \\ \text { that are not widely recognized, and received "reasonable" or "high assurance". }\end{array} \\ \mathbf{5 0} & \begin{array}{l}\text { The entire CSR report was externally verified and received "limited/moderate assurance", } \\ \text { or parts of the CSR report were externally verified and received "reasonable" or "high } \\ \text { assurance". }\end{array} \\ \mathbf{2 5} & \begin{array}{l}\text { The external auditors found significant deficiencies in the CSR report. } \\ \mathbf{0}\end{array}\end{aligned}$

Source: Adapted from Sustainalytics' framework

\section{Findings and Discussion}

Throughout this analysis we compare the general trend of CSR reporting and assurance in Europe with that of American companies, from 2010 to 2014. Regarding the evolution of non-financial reporting for European companies showed in Figure 1, out of the 50 companies analyzed, only $20 \%$ have published a 2014 integrated report that follows best practices or has a GRI Application Level A. However, considering the entire period for which the data for the current study was gathered, there is a $66.6 \%$ increase in the number of companies given the highest score. A higher increase of $80 \%$ is noticeable for the number of companies whose CSR report has a B Application Level, while the number of companies reporting at a C(-) Application Level has increased by 150\%. Consequently, the number of companies in the lowest score categories has recorded a generally negative trend. However, there is the risk of the application level being self-assessed, as the GRI website allows

\section{DE GRUYTER OPEN}

Timisoara Journal of Economics and Business | ISSN: 2286-0991 | www.tjeb.ro Year 2015 | Volume 8 | Issue 1s | Pages: 48-69 
Tînjală, D.-M., Pantea, L. M., Buglea, Al. (2015).

2010-2014: A Comparative Evolution of Sustainability Reporting and its Assurance in Europe and the U.S.A.

companies to score their own sustainability report. It is important to compare these results with the results of the second indicator and to observe how many of these reports have received external assurance for their GRI application levels.

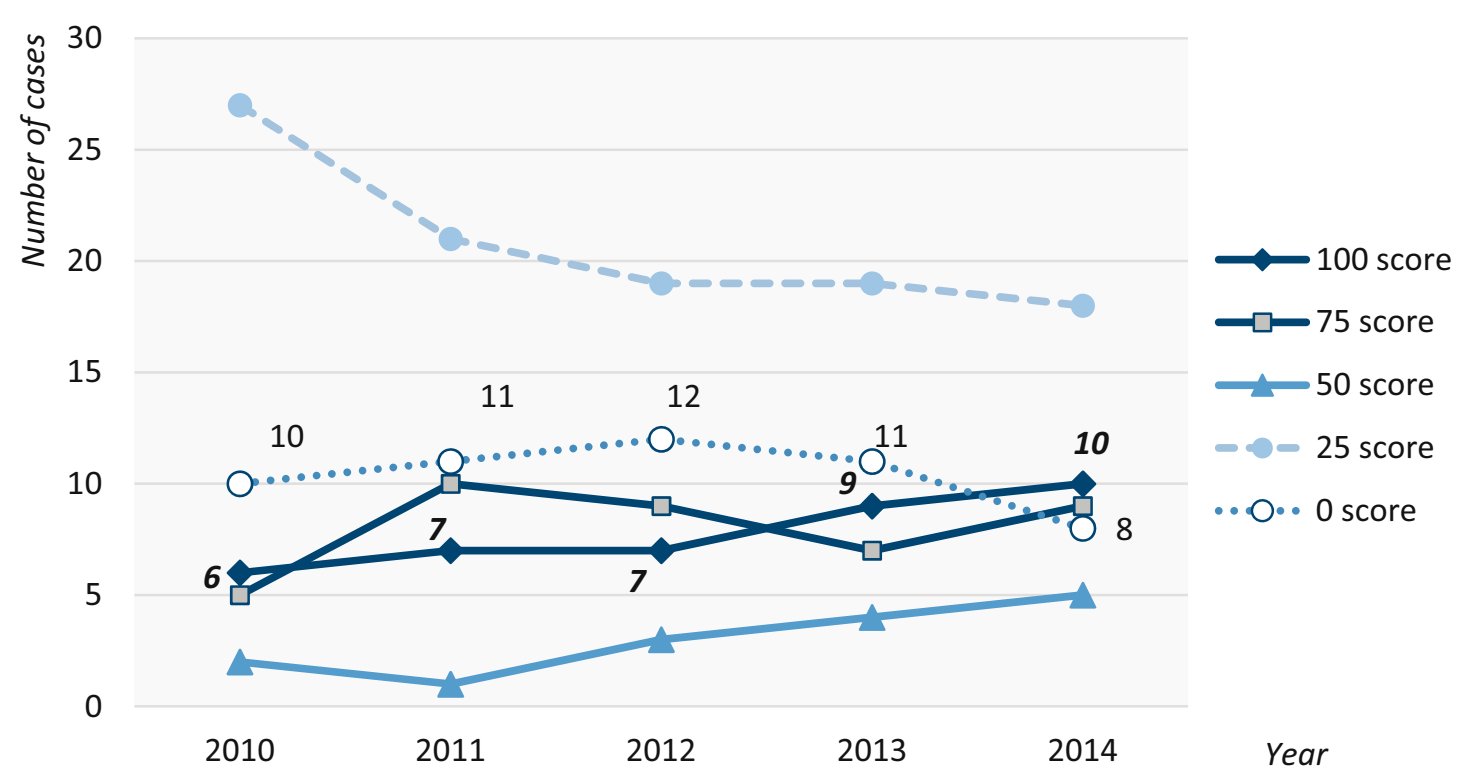

Figure 1. Evolution of the ESG Reporting Standards Indicator for European Companies

Source: Author's results

If we consider reporting in general, $80 \%$ of the European companies analyzed published a CSR report in 2010, compared to $84 \%$ in 2014. Although the increase in reporting rates can be considered small, according to KPMG (2013), European companies serve as an example for other regions in regard to the quality of reporting. Their dominant position can be explained through the adopted national or international sustainability frameworks. Countries such as the United Kingdom, France, Germany, Denmark, Norway and the Netherlands have adopted national regulations or standards for the environmental, social or governance performance of a company, as early as the 1990s. Due to the increasing concern for business ethics, the European Commission has issued the Directive 2013/34/EU with regard to the non-financial reporting.

Compared to European companies, American companies are worse reporters on ESG issues, only 11 out of the 50 analyzed companies publishing a 2014 CSR reported written according to GRI guidelines, 1 having an A Application Level, 9 being assessed as B Application Level and 1 disclosing a C Application Level report.

Between 2010 and 2014, there is no global positive trend for the quality of CSR reporting in American companies, the only mentionable change being the increase in the number of companies rated with a score of 75, from 0 in 2010, to 9 in 2014. If we take into account all reporters regardless of the quality of their disclosures (categories 25, 50, 75 and 100),

\section{DE GRUYTER OPEN}

Timisoara Journal of Economics and Business | ISSN: 2286-0991 | www.tjeb.ro Year 2015 | Volume 8 | Issue 1s | Pages: 48-69 
Tînjală, D.-M., Pantea, L. M., Buglea, Al. (2015).

2010-2014: A Comparative Evolution of Sustainability Reporting and its Assurance in Europe and the U.S.A.

American companies have recorded a $12 \%$ increase in reporting rates, from a total of $42 \%$ reporters in 2010, to $54 \%$ in 2014 . This can be interpreted as an increase in CSR reporting but a lack of development in the quality of the information reported. Considering that more companies have published a CSR report, but the number of companies following the GRI guidelines has been approximately constant, the American companies are susceptible of using CSR reports as a marketing tool rather than a way of communicating decision- altering information to their stakeholders. Although the U.S.A. is a leader on corporate governance issues regulated under the Sarbanes- Oxley act of 2002, most of the US based companies do not go beyond a simple compliance with the law and the regulations.

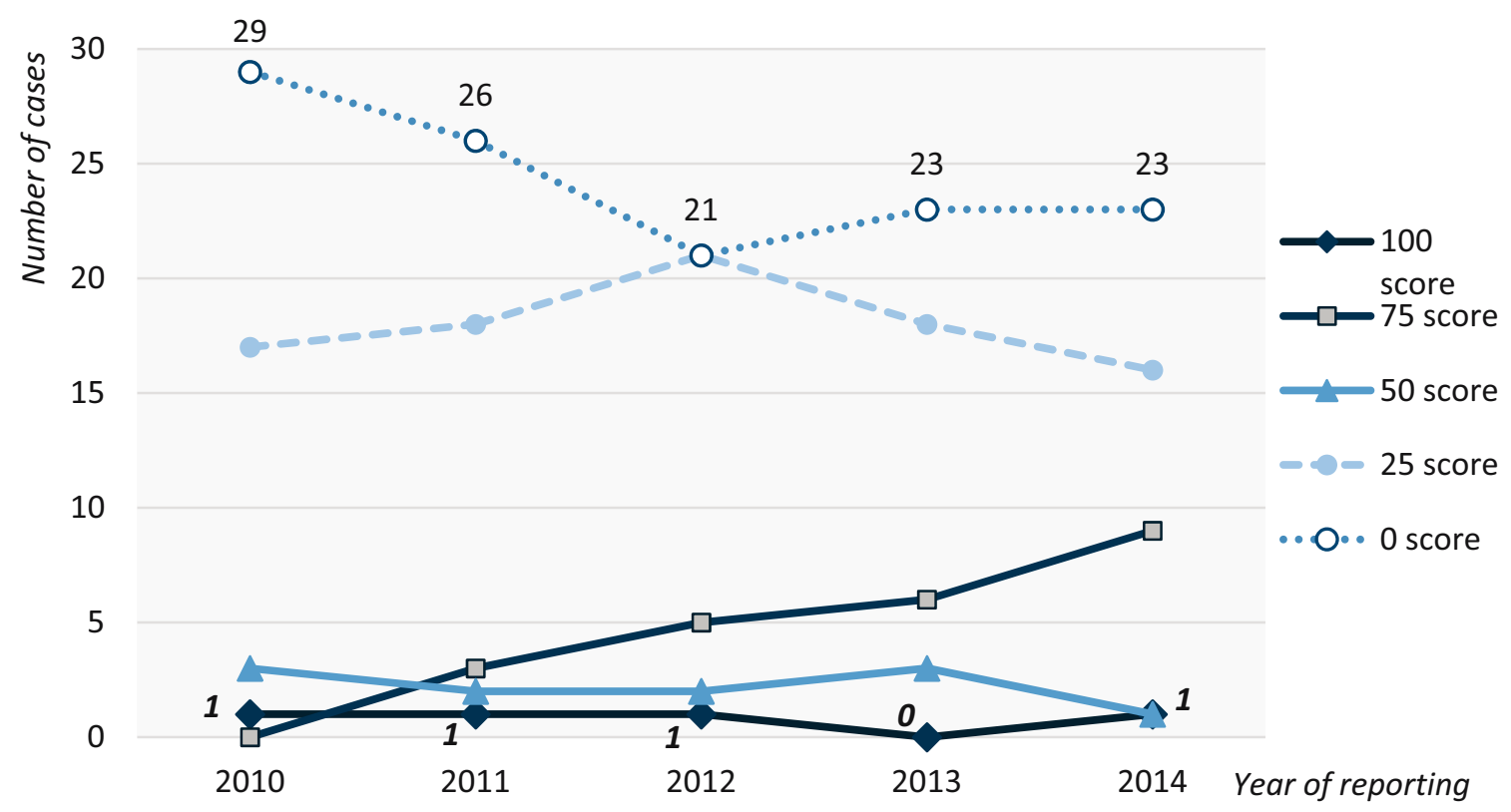

Figure 2. Evolution of the ESG Reporting Standards Indicator for American Companies

Source: Author results

The second indicator we have analyzed is vital towards ensuring the shareholder's trust in the company - the assurance of ESG reporting. Naturally, for companies that did not publish a CSR report, scoring 0 for the first indicator, their reporting category for this second indicator will be the 0 score category - "The CSR report was not externally verified or the company does not publish a CSR report".

However, only an average of $20 \%$ of the European companies included in this study do not publish any non-financial information. According to Figure 3, more than $60 \%$ of the 50 European companies we analyzed either don't publish a CSR report, or do not have it verified by an external party. This means that, over $40 \%$ of the companies that do publish a CSR report do not request the assistance of any external assurance operators to verify the accuracy and credibility of their data, self-assessing and declaring their own GRI application level.

\section{DE GRUYTER OPEN}

Timisoara Journal of Economics and Business | ISSN: 2286-0991 | www.tjeb.ro Year 2015 | Volume 8 | Issue 1s | Pages: 48-69 
Tînjală, D.-M., Pantea, L. M., Buglea, Al. (2015).

2010-2014: A Comparative Evolution of Sustainability Reporting and its Assurance in Europe and the U.S.A.

The quality of sustainability related disclosures for European companies has an increasing trend throughout 2010-2013, decreasing in the first two months of 2014. The sudden negative trend for the 100 and 75 score categories can be explained through the time frame used for this study, which only comprises the first two months of 2014, many companies publishing their CSR reports for the previous year between the months of March and June. Therefore, we consider there is insufficient data to clearly state that the quality in ESG reporting has recorded a decrease for 2014.

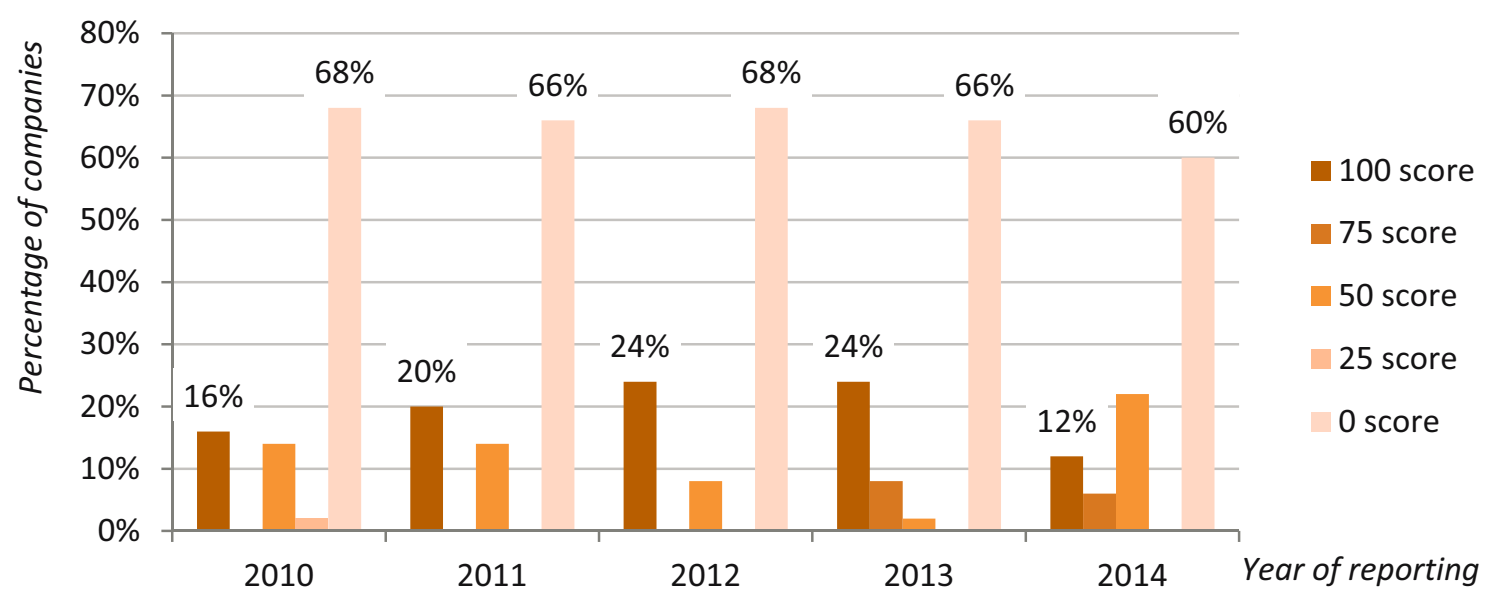

Figure 3. Evolution of the Assurance of ESG Reporting Indicator for European Companies

Source: Author's results

Regarding the American companies and their low performance on CSR reporting in general, there is no surprise that out of the average of $51 \%$ of the companies that report on any nonfinancial information, none of them have their reports externally verified in 2010 and 2011 (Figure 4).

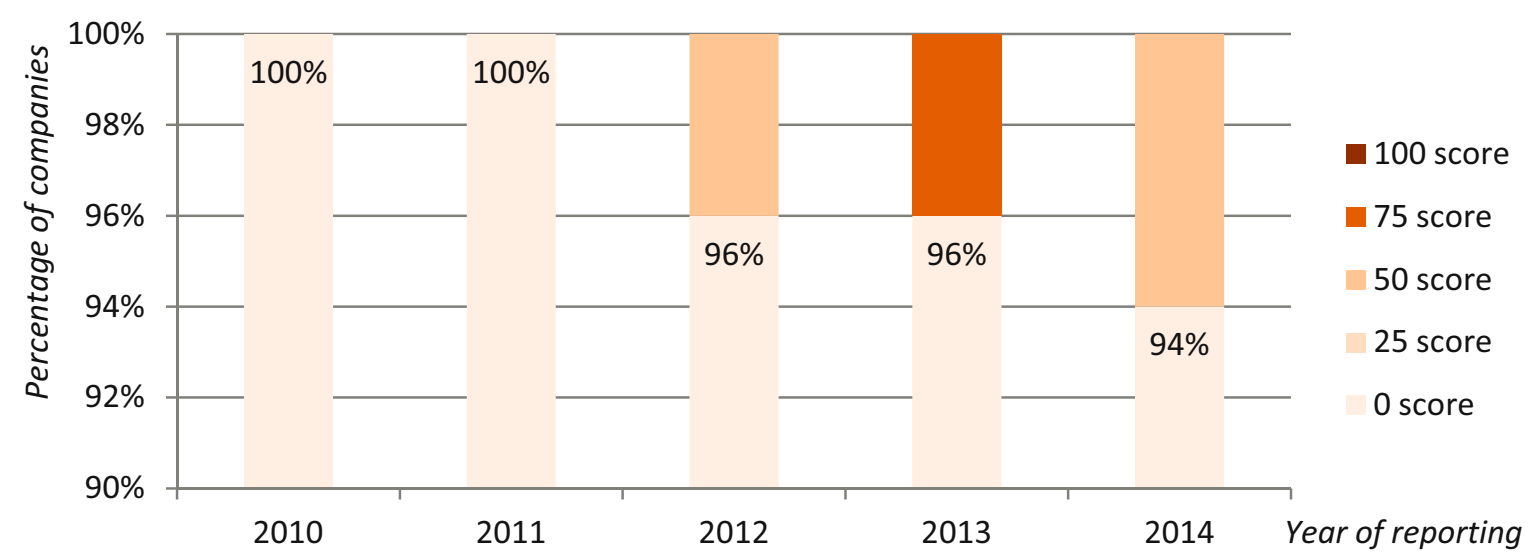

Figure 4. Evolution of the Assurance of ESG Reporting Indicator for American Companies Source: Author's results

DE GRUYTER OPEN
Timisoara Journal of Economics and Business | ISSN: 2286-0991 | www.tjeb.ro Year 2015 | Volume 8| Issue 1s | Pages: 48-69 
Tînjală, D.-M., Pantea, L. M., Buglea, Al. (2015).

2010-2014: A Comparative Evolution of Sustainability Reporting and its Assurance in Europe and the U.S.A.

For 2012, only 2 American companies scored 50 for this indicator, meaning either that their entire CSR report was externally verified and received "limited/moderate assurance", or that parts of the CSR report were externally verified and received "reasonable" or "high assurance." The best performance was reached in 2013, when 2 companies received for their entire CSR report a 75 score, meaning that it was verified according to auditing standards that are not widely recognized, and received "reasonable" or "high assurance." For January and February of 2014, a number of 3 companies have included in their sustainability report a third - party assurance statement granting them a score of 50 .

Although an improvement can be seen in the disclosure and quality of non-financial data in the last 5 years for both regions, American companies are far behind those from Europe (KPMG, 2013) and run the risk to be overcome by companies from Asia, Africa and South America (Daizy et al., 2013; van Zyl, 2013; Meyskens \& Paul, 2010). We believe a more detailed analysis is required to further test our hypothesis.

\section{Conclusion}

Prior research has shown a worldwide evolving trend in sustainability reporting (KPMG, 2013; Daizy et al., 2013; van Zyl, 2013; Meyskens \& Paul, 2010) on which we have based our working hypothesis. However, this article does not take into account just the state of CSR reporting, but also the assessment of such reports. Using more than indicators such as length, language, structure of the report (CSES, 2011; Meyskens \& Paul, 2010), we have tried to ascertain the validity and reliability of published CSR reports, by analysing whether they have been externally assured.

In order for stakeholders and corporate management to mitigate risk and make favourable decisions, they should be correct. It is a modern company's obligation to be transparent regarding its environmental, social and governance related impact by publishing a CSR or an integrated report. After an analysis of such reports for 100 companies, by the courtesy of Sustainalitycs, we have discovered that American companies lag behind European companies on both reporting and the accuracy of data reported. We have explained this phenomenon by the lack of regulation in the US compared to that in Europe. However, we cannot help wondering whether this is the only important reason, or whether there are also cultural ones.

We believe that this study contributes to the existing literature by providing a starting point for other lines of inquiry into this subject. There is limited research on the cultural habits and psychological traits of responsible investors that seem to pressure European companies more than American ones into being responsible. Additionally, another reason to explain the large difference between European and American companies with regards to sustainability reporting could be the different share owning structures in the two areas. While in Europe (especially in Britain) we see a rather cohesive shareowner culture, with relatively few institutions which typically have larger stakes and can impose a bigger pressure on the

\section{DE GRUYTER} OPEN
Timisoara Journal of Economics and Business | ISSN: 2286-0991 | www.tjeb.ro Year 2015 | Volume 8 | Issue 1s | Pages: 48-69 
Tînjală, D.-M., Pantea, L. M., Buglea, Al. (2015).

2010-2014: A Comparative Evolution of Sustainability Reporting and its Assurance in Europe and the U.S.A.

company in terms of sustainability, in the United States, by contrast, we can observe a rather big number of private shareowners resulting in a dispersed ownership. Therefore, shareholders have a limited power to impose sustainability requirements to the companies.

Further developments of the study could also look at whether the external assurance of CSR reports can be correlated with the company's value. Also, it would be interesting to see whether remuneration of the Board of directors is linked to ESG performance or not, expecting a result showing that where there is a direct link, the company is a better reporter than where there is no direct link. Another interesting cause and effect relationship could pertain to stakeholder engagement channels and the quality of corporate disclosure.

\section{Acknowledgements:}

We would like to thank Sustainalytics for granting us access to their sustainability ratings data. Sustainalytics is an ESG research and analysis firm that provides data for responsible investors worldwide. The company has been a part of the sustainability analysis market for more than 20 years and, at present, it provides global research coverage through its 14 offices.

\section{References}

AccountAbility. (2008) AA1000 Accountability Principles Standard 2008. Retrieved May 5, 2014 from http://www.accountability.org/images/content/0/7/074/AA1000APS\% 202008.pdf

AccountAbility. (2014). Accountability - Setting the Standard for Corporate Responsibility and Sustainable Development. Retrieved May 5, 2014 from http://www.account ability.org

Anis, C., Lala-Popa, I., Cican, S., \& Tarta (Blaga), E. A. (2012). Performance Measurement through Non-financial Indicators. Annals of the University of Oradea, Romania: Economic Science Series, 1(1), 468-473.

Baden, D., \& Harwood, I. (2013). Terminology Matters: A critical exploration of Corporate Social Responsibility Terms. Journal of Business Ethics, 116(3), 615-627.

Bassen, A., \& Kovacs, A.M. (2008). Environmental, Social and Governance Key Performance Indicators from a Capital Market Perspective. Zeitschrift fur Wirtschafts und Unternehmensethik, 9(2), 182-192.

Centre for Strategy and Evaluation Services (CSES). (2011). Disclosure of non-financial information by companies. Retrieved April 11, 2014 from http://ec.europa.eu/ internal_market/accounting/docs/non-financial-reporting/com_2013_207-study_ en.pdf

Christofi, A., Christofi, P., \& Sisaye, S. (2012). Corporate sustainability: Historical development and reporting practices. Management Research Review, 35(2), 157-172.

Daizy, Mitali, S., \& Niladri, D. (2013). Corporate sustainability reporting: A review of initiatives and trends. The IUP Journal of Accounting Research \& Audit Practices, 12(2), 7-18.

Deloitte (2012). Disclosure of long-term business value. What matters? Retrieved August 4, 2014 from http://www.deloitte.com/assets/Dcom-UnitedStates/Local\%20Assets /Documents/us_scc_materialitypov_032812.pdf

\section{DE GRUYTER OPEN} Year 2015 | Volume 8 | Issue 1s | Pages: 48-69 
Tînjală, D.-M., Pantea, L. M., Buglea, Al. (2015).

2010-2014: A Comparative Evolution of Sustainability Reporting and its Assurance in Europe and the U.S.A.

Deutsche Gesellschaft fur Internationale Zusammenarbeit (GIZ), GRI Focal Point India \& Thought Arbitrage Research Institute. (2012). Sustainability Reporting - Practices and Trends in India 2012. New Delhi.

Deutsche Vereinigung für Finanzanalyse und Asset Management (DVFA) \& The European Federation of Financial Analysts Societies (EFFAS). (2010). KPIS for ESG. Retrieved May 30, 2014 from http://www.effas-esg.com/wp-content/uploads/2011/07/KPIs_ for_ESG_3_0_Final.pdf

European Commission. (2011). A renewed EU strategy 2011-14 for Corporate Social Responsibility. Retrieved May 10, 2014 from http://eur-lex.europa.eu/LexUriServ/ LexUriServ.do?uri=COM:2011:0681:FIN:EN:PDF

European Commission. (2013). An analysis of Policy References made by large EU Companies to Internationally Recognised CSR Guidelines and Principles, Retrieved May 5, 2014 from http://ec.europa.eu/enterprise/policies/sustainable-business/ files/csr/csr-guide-princ-2013_en.pdf

European Union. (2013). Directive 2013/34/EU on the annual financial statements, consolidated financial statements and related reports of certain types of undertakings.

Global Reporting Initiative. (2013). The external assurance of sustainability reporting. Research and Development Series. Retrieved May 1, 2014 from https://www. globalreporting.org/resourcelibrary/GRI-Assurance.pdf

Global Reporting Initiative (2014). What is GRI? Retrieved April 11, 2014 from https://www. globalreporting.org/information/about-gri/what-is-GRI/Pages/default.aspx

Institute of Chartered Accountants in England \& Wales (ICAEW). (2004). Sustainability: the role of accountants. London, Retrieved April 12, 2014 from http://www.icaew.com/ en/technical/financial-reporting/information-for-better-markets/ifbm-reports/ sustainability-the-role-of-accountants

International Auditing and Assurance Standards Board (IAASB). (2012). Handbook of International Quality Control, Auditing, Review, Other Assurance, and Related Services Pronouncements. International Federation of Accountants.

International Auditing and Assurance Standards Board (IAASB). (2013). International Standard on Assurance Engagements (ISAE) 3000 Revised, Assurance Engagements Other than Audits or Reviews of Historical Financial Information. International Federation of Accountants.

International Integrated Reporting Council. (2013). The International IR Framework. Retrieved May 3, 2014 from http://www.theiirc.org/international-ir-framework

loannou, I., \& Serafeim, G. (2011). The Consequences of Mandatory Sustainability Reporting. Harvard Business School Working Paper, Retrieved 15 May 2014 from http://www.hbs.edu/faculty/Publication\%20Files/11-100_7f383b79-8dad-462d90df-324e298acb49.pdf

KPMG (2013). The KPMG survey of corporate responsibility reporting, Retrieved April 14, 2014 from http://www.kpmg.com/Global/en/IssuesAndInsights/ArticlesPublications /corporate-responsibility/Documents/corporate-responsibility-reporting-survey2013.pdf

KPMG, \& WIMM. (2002). KPMG International Study of Corporate Sustainability Reporting 2002. Drukgroep Maasland, Maasland.

Krippendorff, K. (1989). Content analysis. University of Pennsylvania, Annenberg School for Communication Departamental Papers, Retrieved May 4, 2014 from http://repository. upenn.edu/asc_papers/226

Manetti, G., \& Becatti, L. (2009). Assurance Services for Sustainability Reports: Standards and Empirical Evidence. Journal of Business Ethics, 87, 289-298. 
Tînjală, D.-M., Pantea, L. M., Buglea, Al. (2015).

2010-2014: A Comparative Evolution of Sustainability Reporting and its Assurance in Europe and the U.S.A.

Meyskens, M., \& Paul, K. (2010). The Evolution of Corporate Social Reporting Practices in Mexico. Journal of Business Ethics, 91, 211-227.

Milne, M., \& Gray, R. (2013). W(h)ither Ecology? The Triple Bottom Line, the Global Reporting Initiative, and Corporate Sustainability Reporting. Journal of Business Ethics, 118(1), 13-29.

Moore, W. (2012). Sustainability reporting: A work in progress. Journal of Sustainability and Green Business, 2. Retrieved April 15, 2014, from http://www.aabri.com/jsgb.html

Norgaard, R. (1988). Sustainable Development - a co-evolutionary view. Futures, 20(6), 606-620.

O'Dwyer, B., \& Owen, D. (2007). Seeking stakeholder-centric sustainability assurance. Journal of Corporate Citizenship, 2007(25), 77-94.

Pezzey, J., \& Toman, M. (2002). The Economics of Sustainability: A review of Journal Articles. Resources for the future, Discussion Paper 02-03.

Sen, M., \& Das, N. (2013). Corporate Sustainability Reporting: A Review of Initiatives and Trends. The IUP Journal of Accounting Research \& Audit Practices, 12(2), 7-18.

Tschopp, D., \& Nastaski, M. (2013). The Harmonization and Convergence of Corporate Social Responsibility Reporting Standards. Journal of Business Ethics, 125(1), 147-162.

UNGC. (2014). United Nations Global Compact website. Retrieved May 3, 2014 from http://www.unglobalcompact.org

van Zyl, A. (2013). Sustainability and Integrated Reporting in the South African Corporate Sector. International Business \& Economics Research Journal, 12(8), 903-926.

World Business Council for Sustainable Development (WBCSD). (2002a). The Business Case for Sustainable Development. Retrieved April 12, 2014 from http://www.wbcsd. org/pages/edocument/edocumentdetails.aspx?id=197\&nosearchcontextkey=true

World Business Council for Sustainable Development (WBCSD). (2002b). Sustainable Development Reporting - Striking the Balance. Geneva. Retrieved April 12, 2014 from http://www.wbcsd.org/pages/edocument/edocumentdetails.aspx?id=144\& nosearchcontextkey=true

World Commission on Environment and Development. (1987). Our common future. Retrieved May 15, 2014 from http://www.un-documents.net/wced-ocf.htm 
Tînjală, D.-M., Pantea, L. M., Buglea, Al. (2015). of Economics and Business

2010-2014: A Comparative Evolution of Sustainability Reporting and its Assurance in Europe and the U.S.A.

APPENDIX A- Selected European companies

\begin{tabular}{|c|c|c|c|}
\hline & Country & Company & Peer group/ Sector \\
\hline 1 & Austria & Kommunalkredit Austria AG & Banks \\
\hline 2 & Austria & Strabag SE & Construction \& Engineering \\
\hline 3 & Austria & Telekom Austria AG & Telecommunication Services \\
\hline 4 & Belgium & Belgacom SA & Telecommunication Services \\
\hline 5 & Denmark & Danske Bank A/S & Banks \\
\hline 6 & Denmark & Novo Nordisk A/S & Pharmaceuticals \\
\hline 7 & Finland & Aktia Real Estate Mortgage Bank PLC & Banks \\
\hline 8 & Finland & Sampo Oyj & Insurance \\
\hline 9 & France & Bollore & Transportation \\
\hline 10 & France & Caisse des Depots et Consignations & Banks \\
\hline 11 & France & Christian Dior SA & Textiles \& Apparel \\
\hline 12 & France & Eutelsat Communications & Media \\
\hline 13 & France & L'Oreal SA & Household Products \\
\hline 14 & France & Renault SA & Automobiles \\
\hline 15 & France & Reseau Ferre de France & Transportation Infrastructure \\
\hline 16 & France & Safran SA & Aerospace \& Defense \\
\hline 17 & France & Schneider Electric S.A. & Electrical Equipment \\
\hline 18 & Germany & Bertelsmann AG & Media \\
\hline 19 & Germany & Continental AG & Auto Components \\
\hline 20 & Germany & Drillisch AG & Telecommunication Services \\
\hline 21 & Germany & Fraport AG & Transportation Infrastructure \\
\hline 22 & Germany & Lanxess AG & Chemicals \\
\hline 23 & Germany & NRW.BANK & Banks \\
\hline 24 & Germany & Solarworld AG & Semiconductors \\
\hline 25 & Ireland & Kerry Group plc & Food Products \\
\hline 26 & Ireland & Seagate Technology PLC & Technology Hardware \\
\hline 27 & Italy & Autogrill SpA & Consumer Services \\
\hline 28 & Italy & Mediobanca S.p.a. & Diversified Financials \\
\hline 29 & Italy & Prysmian S.p.A. & Electrical Equipment \\
\hline 30 & Netherlands & ASM International NV & Semiconductors \\
\hline 31 & Norway & Sparebanken Vest & Banks \\
\hline 32 & Norway & Yara International ASA & Chemicals \\
\hline 33 & Spain & Iberdrola SA & Utilities \\
\hline 34 & Sweden & $A B$ Volvo & Machinery \\
\hline 35 & Sweden & Assa Abloy AB & Building Products \\
\hline 36 & Sweden & Ericsson & Technology Hardware \\
\hline 37 & Sweden & Husqvarna $A B$ & Consumer Durables \\
\hline 38 & Sweden & Modern Times Group Mtg AB & Media \\
\hline 39 & Sweden & Skanska AB & Construction \& Engineering \\
\hline 40 & Sweden & SKF AB & Machinery \\
\hline 41 & Switzerland & Nestle S.A. & Food Products \\
\hline 42 & United Kingdom & Aviva plc & Insurance \\
\hline 43 & United Kingdom & British American Tobacco plc & Food Products \\
\hline 44 & United Kingdom & Daily Mail and General Trust plc & Media \\
\hline 45 & United Kingdom & ICAP plc & Diversified Financials \\
\hline 46 & United Kingdom & IMI PLC & Machinery \\
\hline 47 & United Kingdom & Investec plc & Diversified Financials \\
\hline 48 & United Kingdom & Legal \& General Group Plc & Insurance \\
\hline 49 & United Kingdom & National Grid plc & Utilities \\
\hline 50 & United Kingdom & Serco Group PIc & Commercial Services \\
\hline
\end{tabular}

\section{DE GRUYTER OPEN}

Timisoara Journal of Economics and Business | ISSN: 2286-0991 | www.tjeb.ro Year 2015 | Volume 8 | Issue 1s | Pages: 48-69 
Tînjală, D.-M., Pantea, L. M., Buglea, Al. (2015).

2010-2014: A Comparative Evolution of Sustainability Reporting and its Assurance in Europe and the U.S.A.

APPENDIX B - Selected American companies

\begin{tabular}{|c|c|c|c|}
\hline & Country & Company & Peer group/ Sector \\
\hline 1 & United States & Aflac Inc. & Insurance \\
\hline 2 & United States & Agilent Technologies Inc. & Pharmaceuticals \\
\hline 3 & United States & American Express Company & Diversified Financials \\
\hline 4 & United States & American Water Works Company, Inc. & Utilities \\
\hline 5 & United States & Aqua America Inc. & Utilities \\
\hline 6 & United States & Archer Daniels Midland Company & Food Products \\
\hline 7 & United States & Associated Banc-Corp & Banks \\
\hline 8 & United States & BlackRock, Inc. & Diversified Financials \\
\hline 9 & United States & BorgWarner Inc. & Auto Components \\
\hline 10 & United States & Calpine Corp. & Utilities \\
\hline 11 & United States & Capital One Financial Corp. & Diversified Financials \\
\hline 12 & United States & Cincinnati Financial Corp. & Insurance \\
\hline 13 & United States & Colgate-Palmolive Co. & Household Products \\
\hline 14 & United States & Comerica Incorporated & Banks \\
\hline 15 & United States & Crown Holdings Inc. & Containers \& Packaging \\
\hline 16 & United States & Deere \& Company & Machinery \\
\hline 17 & United States & DeVry, Inc. & Consumer Services \\
\hline 18 & United States & Electronic Arts Inc. & Software \& Services \\
\hline 19 & United States & EMC Corporation & Technology Hardware \\
\hline 20 & United States & FedEx Corporation & Transportation \\
\hline 21 & United States & Forest City Enterprises Inc. & Real Estate \\
\hline 22 & United States & Hologic Inc. & Healthcare \\
\hline 23 & United States & Illinois Tool Works Inc. & Machinery \\
\hline 24 & United States & Iron Mountain Inc. & Commercial Services \\
\hline 25 & United States & ITT Educational Services Inc. & Consumer Services \\
\hline 26 & United States & Joy Global, Inc. & Machinery \\
\hline 27 & United States & Life Technologies Corporation & Pharmaceuticals \\
\hline 28 & United States & Manitowoc Co. Inc. & Machinery \\
\hline 29 & United States & Mastercard Incorporated & Software \& Services \\
\hline 30 & United States & Mattel Inc. & Consumer Durables \\
\hline 31 & United States & Monsanto Co. & Chemicals \\
\hline 32 & United States & Newfield Exploration Co. & Oil \& Gas Producers \\
\hline 33 & United States & ONEOK Inc. & Utilities \\
\hline 34 & United States & Oracle Corporation & Software \& Services \\
\hline 35 & United States & PACCAR Inc. & Machinery \\
\hline 36 & United States & Peabody Energy Corp. & Oil \& Gas Producers \\
\hline 37 & United States & PepsiCo, Inc. & Food Products \\
\hline 38 & United States & PNC Financial Services Group Inc. & Banks \\
\hline 39 & United States & PPG Industries Inc. & Chemicals \\
\hline 40 & United States & Quanta Services, Inc. & Construction \& Engineering \\
\hline 41 & United States & Rayonier Inc. & Real Estate \\
\hline 42 & United States & Scripps Networks Interactive, Inc. & Media \\
\hline 43 & United States & Southern Company & Utilities \\
\hline 44 & United States & SPX Corporation & Machinery \\
\hline 45 & United States & Sysco Corp. & Food Retailers \\
\hline 46 & United States & The Clorox Company & Household Products \\
\hline 47 & United States & The Travelers Companies, Inc. & Insurance \\
\hline 48 & United States & Thomson Reuters Corporation & Media \\
\hline 49 & United States & Unum Group & Insurance \\
\hline 50 & United States & Williams Companies, Inc. & Refiners \& Pipelines \\
\hline
\end{tabular}

DE GRUYTER OPEN 
Tînjală, D.-M., Pantea, L. M., Buglea, Al. (2015).

2010-2014: A Comparative Evolution of Sustainability Reporting and its Assurance in Europe and the U.S.A.

APPENDIX C- Percentage of companies reporting, for each indicator category

\begin{tabular}{|c|c|c|c|c|c|c|c|c|c|c|c|}
\hline & \multicolumn{6}{|c|}{ ESG Reporting Standards } & \multicolumn{5}{|c|}{ Assurance of ESG Reporting } \\
\hline \multirow{6}{*}{ 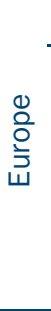 } & Score/ Year & 2010 & 2011 & 2012 & 2013 & 2014 & 2010 & 2011 & 2012 & 2013 & 2014 \\
\hline & 100 score & $12 \%$ & $14 \%$ & $14 \%$ & $18 \%$ & $20 \%$ & $16 \%$ & $20 \%$ & $24 \%$ & $24 \%$ & $12 \%$ \\
\hline & 75 score & $10 \%$ & $20 \%$ & $18 \%$ & $14 \%$ & $18 \%$ & $0 \%$ & $0 \%$ & $0 \%$ & $8 \%$ & $6 \%$ \\
\hline & 50 score & $4 \%$ & $2 \%$ & $6 \%$ & $8 \%$ & $10 \%$ & $14 \%$ & $14 \%$ & $8 \%$ & $2 \%$ & $22 \%$ \\
\hline & 25 score & $54 \%$ & $42 \%$ & $38 \%$ & $38 \%$ & $36 \%$ & $2 \%$ & $0 \%$ & $0 \%$ & $0 \%$ & $0 \%$ \\
\hline & 0 score & $20 \%$ & $22 \%$ & $24 \%$ & $22 \%$ & $16 \%$ & $68 \%$ & $66 \%$ & $68 \%$ & $66 \%$ & $60 \%$ \\
\hline \multirow{5}{*}{ 宫 } & 100 score & $2 \%$ & $2 \%$ & $2 \%$ & $0 \%$ & $2 \%$ & $0 \%$ & $0 \%$ & $0 \%$ & $0 \%$ & $0 \%$ \\
\hline & 75 score & $0 \%$ & $6 \%$ & $10 \%$ & $12 \%$ & $18 \%$ & $0 \%$ & $0 \%$ & $0 \%$ & $4 \%$ & $0 \%$ \\
\hline & 50 score & $6 \%$ & $4 \%$ & $4 \%$ & $6 \%$ & $2 \%$ & $0 \%$ & $0 \%$ & $4 \%$ & $0 \%$ & $6 \%$ \\
\hline & 25 score & $34 \%$ & $36 \%$ & $42 \%$ & $36 \%$ & $32 \%$ & $0 \%$ & $0 \%$ & $0 \%$ & $0 \%$ & $0 \%$ \\
\hline & 0 score & $58 \%$ & $52 \%$ & $42 \%$ & $46 \%$ & $46 \%$ & $100 \%$ & $100 \%$ & $96 \%$ & $96 \%$ & $94 \%$ \\
\hline
\end{tabular}

Timisoara Journal of Economics and Business | ISSN: 2286-0991 | www.tjeb.ro Year 2015 | Volume 8 | Issue 1s | Pages: 48-69 